\title{
Invertebrate larval distributions influenced by adult habitat distribution, larval behavior, and hydrodynamics in the retentive upwelling shadow of Monterey Bay, California, USA
}

\author{
Erin V. Satterthwaite ${ }^{1,2,3,5, *}$, John P. Ryan ${ }^{4}$, Julio B. J. Harvey ${ }^{4}$, Steven G. Morgan ${ }^{1,2}$ \\ ${ }^{1}$ Coastal Marine Sciences Institute and Bodega Marine Laboratory, University of California Davis, Bodega Bay, CA 94923, USA \\ ${ }^{2}$ Department of Environmental Science and Policy, University of California Davis, Davis, CA 95616, USA \\ ${ }^{3}$ National Center for Ecological Analysis and Synthesis, University of California, Santa Barbara, CA 93101, USA \\ ${ }^{4}$ Monterey Bay Aquarium Research Institute, Moss Landing, CA 95039, USA
}

${ }^{5}$ Present address: California Sea Grant, Scripps Institution of Oceanography, University of California, San Diego, La Jolla, CA 92093, USA

\begin{abstract}
Larval dispersal phases are a key determinant of population dynamics in recruitment-limited, coastal upwelling regions. Larvae were long considered to be highly susceptible to offshore transport, except in the lee of headlands where eddies form during upwelling conditions. We examined the spatial variation of benthic invertebrate larval assemblages in relation to the retentive upwelling shadow in northern Monterey Bay (California, USA) during strong upwelling (August 2013) and weak upwelling (October 2013). We characterized the spatial variation in physical characteristics of the water column, determined the cross-shore and depth distributions of invertebrate larvae in relation to the upwelling shadow, and examined how these physical and biological patterns change with upwelling strength. Larval abundances and environmental data (water temperature, salinity, chlorophyll a concentration) were collected simultaneously using a plankton pump and profiling CTD at 3 depths: above, within, and below the chlorophyll a maximum layer. Larvae were primarily detected near the bottom. Larvae of most taxa were positively associated with a subsurface chlorophyll a maximum layer in August, but not in October when this layer was near the surface. Adult habitat distribution was related to the spatial distribution of larvae. Larvae of nearshore taxa occurred in the inner bay, while larvae of predominately offshore taxa occurred in the outer bay. Taxa with similar adult habitat (nearshore versus offshore) cooccurred in water samples. In addition, larvae of offshore taxa were commonly associated with offshore water types. Thus, the distribution of larvae within northern Monterey Bay appears to be strongly influenced by adult habitat distribution, vertical positioning of larvae in the water column, and upwelling strength.
\end{abstract}

KEY WORDS: Invertebrate larvae - Dispersal - Retention · Behavior - Upwelling shadow • Chlorophyll a $\cdot$ Monterey Bay $\cdot$ California Current

\section{INTRODUCTION}

One of the main goals of ecology is to quantify distributions and abundances of organisms and to elucidate the processes that influence population and community dynamics. Population dynamics are dri-

*Corresponding author: esatterthwaite@ucsd.edu ven by the inputs to (birth and immigration) and outputs from (death and emigration) a population. The latter can be affected by numerous, often interacting, physical and biological processes. In marine systems, many species have a dispersing larval phase, which is a key determinant of population dynamics, espe-

(C) The authors 2021. Open Access under Creative Commons by Attribution Licence. Use, distribution and reproduction are unrestricted. Authors and original publication must be credited. 
cially in recruitment-limited upwelling regions (Thorson 1950, Gaines \& Roughgarden 1987). Larval phases add complexity to understanding population dynamics. They are difficult to track due to their small size (Levin 2006), are often patchily distributed, utilize a different habitat than the adult phase (i.e. pelagic for larvae and benthic for adult), and are therefore challenging to sample (Pineda et al. 2007). Thus, the suite of factors that influence marine invertebrate population dynamics is extensive and includes processes operating at multiple spatial and temporal scales in nearshore coastal habitats (Eckman 1996).

Since several of the windiest upwelling regions are thought to be recruitment-limited, meaning that larval supply is a key determinant of population dynamics, they provide useful study systems for elucidating patterns and processes affecting the distributions and abundance of larvae (Yoshioka 1982, Roughgarden et al. 1988). In the northern hemisphere, eastern boundary upwelling regions are characterized by strong northwesterly winds in the spring and summer, which, coupled with the Coriolis effect, transport surface water offshore (Chavez \& Messié 2009). This displacement of nearshore surface waters draws cold, nutrient-rich waters to the surface into the nearshore environment to support the most productive marine ecosystems in the world (Pauly \& Christensen 1995). Previous work suggests that persistent upwelling winds may rapidly transport larvae offshore, thereby limiting delivery to nearshore communities (Yoshioka 1982, Roughgarden et al. 1988), yet recent studies show that all stages of larvae from many taxa are found nearshore during upwelling conditions (Poulin et al. 2002a,b, Morgan et al. 2009a, 2018, Shanks \& Shearman 2009, Bartilotti et al. 2014, Fisher et al. 2014, Bonicelli et al. 2016).

Higher abundances of larvae nearshore are influenced by physical and behavioral mechanisms. For example, coastal topography in upwelling regions, such as headlands and bays, interacts with coastal circulation patterns to create nearshore retention zones, known as upwelling shadows (Graham et al. 1992, Wing et al. 1998, Mace \& Morgan 2006, Morgan et al. 2011b). Upwelling shadows develop during spring to fall when cold, upwelled water is advected alongshore past an open bay or the lee of a coastal headland, generating cyclonic circulation inshore of the upwelling flow. Locally enhanced retention in the upwelling shadow results in surface warming due to solar heating and nutrient depletion due to phytoplankton uptake, leading to a region of warm, stratified, nutrient-depleted water (Graham \& Lar- gier 1997, Roughan et al. 2005). Upwelling shadows are ecologically important, as they retain phytoplankton, holoplankton, and larvae of many species (Graham et al. 1992, Wing et al. 1998, Mace \& Morgan 2006, Morgan \& Fisher 2010, Morgan et al. 2011b, Ryan et al. 2014a,b, Harvey et al. 2018) and are associated with increased settlement (Wing et al. 1995, Morgan et al. 2009b).

Depth regulation by larvae can increase the likelihood that larvae can return to adult habitats in upwelling regimes (reviewed by Morgan 2014). Since currents vary throughout the water column, the time that larvae spend at different depths affects the direction and extent of larval transport (Queiroga \& Blanton 2004). Thus, larvae employ different depthmodification 'strategies' over varying timescales. Larvae may occur at a specific depth throughout the duration of larval development or migrate vertically over the course of larval development, known as ontogenetic vertical migration. Larvae may also migrate vertically on shorter timescales, in relation to tidal or diel cycles, or in response to environmental changes, such as variation in light, temperature, salinity, or hydrostatic pressure (Queiroga \& Blanton 2004, Miller \& Morgan 2013, Morgan 2014, 2020, Epifanio \& Cohen 2016). Nearshore species utilize one or combinations of these behaviors to mediate larval transport to suitable adult habitats.

Larval migrations range from short to long distances, such that larvae may remain nearshore or in estuarine habitats, or migrate to the outer shelf, depending on the time spent in surface currents (Morgan 2014). For example, larvae may be transported away from adult habitats in seaward-flowing surface waters and return to adult habitats by descending into shoreward-flowing bottom currents (Morgan et al. 2009a, 2018, Morgan \& Fisher 2010). Consequently, larval concentrations tend to increase closer to shore, even in recruitment-limited upwelling regions (Shanks \& Shearman 2009, Nickols et al. 2013, Fisher et al. 2014, Morgan et al. 2009c, 2018). Thus, determining the effects of nearshore physical processes on larval supply is necessary for understanding recruitment dynamics, especially in regions characterized by strong coastal upwelling. Additionally, larval foraging behaviors can influence distributions (Woodson \& McManus 2007). Phytoplankton accumulate near fronts and clines where larvae forage in high-density food patches (Woodson \& McManus 2007, McManus et al. 2008, Ryan et al. 2010a, Woodson et al. 2012). The upwelling shadow in Monterey Bay (California, USA) is an important area for the development of phytoplankton blooms 
(McManus et al. 2008), which are an essential requirement for larval growth and survival (Lasker 1975). Therefore, larval presence may correspond with chlorophyll a (chl a) concentration, due to foraging behavior or passive accumulation.

Most studies of larval distributions in upwelling regions have been conducted during the peak upwelling season, but variation in seasonal oceanographic conditions (Pennington \& Chavez 2000) and the persistence of the upwelling shadow in Monterey Bay have been observed (Graham \& Largier 1997). Additionally, these studies have focused on a relatively narrow taxonomic scope (e.g. barnacles, crabs, or fishes). The goal of our study was to determine if interspecific differences in cross-shelf transport regulated by vertical positioning of larvae in the water column occur in Monterey Bay, as has been documented at other locations (Mor-
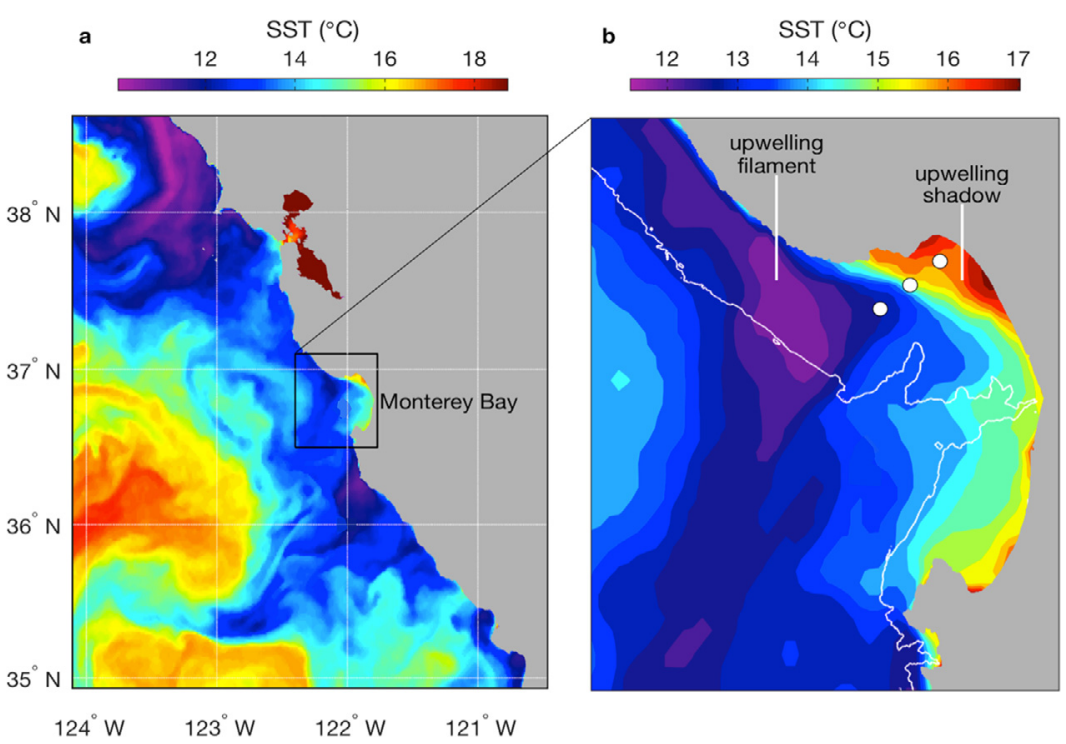

Fig. 1. Sea surface temperature (SST) in Monterey Bay, California, and vicinity on 2 October 2013 at 21:37 h UTC. Identical SST data are represented according to the different ranges at each scale: (a) along the central Californian coast and (b) in Monterey Bay. White circles in (b) mark the locations of CTD water sampling stations along the transect that were repeatedly sampled for benthic invertebrate larvae during August and October 2013. Autonomous underwater vehicle (AUV) surveys were conducted parallel to this transect. The white contour (100 $\mathrm{m}$ isobath) in (b) defines the shelf break gan et al. 2009a, Morgan \& Fisher

2010, Nickols et al. 2013, Morgan 2014), and if these behaviors are consistent across differing oceanographic conditions. Variation in source waters entering Monterey Bay affected the composition of the larval assemblage, such that offshore species were more abundant in October, whereas nearshore species predominated in August (Satterthwaite et al. 2020). This study complements that of Satterthwaite et al. (2020) by (1) characterizing the spatial variation in physical characteristics of the water column, (2) assessing the cross-shore and depth distributions of larvae relative to the upwelling shadow, and (3) examining how these physical and biological patterns change with varied oceanographic conditions.

\section{MATERIALS AND METHODS}

\subsection{Field surveys}

We conducted 2 cruises aboard the RV 'Rachel Carson' in northern Monterey Bay during late summer (12-16 August) and early fall (22-25 October) of 2013. We sampled 3 stations along an $8 \mathrm{~km}$ transect that extended from the inner bay, within the upwelling shadow, to the outer bay, just outside of the upwelling shadow (Fig. 1). We refer to cross-shore stations by their approximate distance from the nearest perpendicular onshore reference point (Aptos Creek: $36.969^{\circ} \mathrm{N}, 121.907^{\circ} \mathrm{W}$ ): $4 \mathrm{~km}$ (inner bay), 8 $\mathrm{km}$ (mid-bay), and $12 \mathrm{~km}$ (outer bay). All sampling was conducted between early morning and midafternoon, and stations were sampled in the same order on each day (inner to mid- to outer bay). At each station, we adaptively sampled 3 depths relative to the chl a maximum layer (hereafter $\mathrm{C}_{\max }$ ). This layer of elevated chl a concentrations and the depth of peak concentrations were defined in real time by monitoring CTD environmental data during each cast. The depths of the $C_{\max }$ peak ranged from 2 to 31 $\mathrm{m}$ over the course of the study.

At each station, plankton samples were collected above, within, and below the $\mathrm{C}_{\max }$, using a gaspowered pump. We pumped 2401 of seawater per min for $10 \mathrm{~min}$ and sampled $2.4 \mathrm{~m}^{3}$ of seawater per depth. Samples were filtered through a $115 \mu \mathrm{m}$ mesh plankton net that was suspended over the side of the ship's rail, with the cod end submerged beneath the sea surface. Samples were preserved in 95\% ethanol. Samples were split with a Folsom plankton splitter, and we identified the developmental stages of benthic invertebrate larvae using a dissecting microscope. Larvae initially identified to species were sub- 
sequently grouped to class or order for data analysis due to low overall abundances. We then grouped larvae into early stages (e.g. early zoeae), late stages (e.g. late zoeae), and postlarvae (e.g. megalopae). In addition, we used high throughput DNA sequencing of the mitochondrial cytochrome- $c$-oxidase subunit-I gene $(C O I)$ to resolve taxa that were challenging to morphologically identify to species. Taxonomic names were assigned to operational taxonomic unit sequences by comparing them to custom reference sequence databases using the Basic Local Alignment Search Tool (BLAST). Descriptions of the complete molecular methods have been published (Harvey et al. 2018).

The hose from the plankton pump was attached to the outside of the CTD package frame. The profiling CTD package (Sea-Bird Scientific) measured temperature, salinity (Sea-Bird Scientific SBE 911Plus CTD), and chl a concentration (Wetlabs WetStar WS3S fluorometer) throughout the water column.

In addition to the CTD, the Monterey Bay Aquarium Research Institute (MBARI) autonomous underwater vehicle (AUV) 'Dorado' was deployed concurrently to measure physical, optical, and chemical oceanographic characteristics along the entire length of the transect during each day of sampling. Detailed AUV sampling methods have been previously published (Satterthwaite et al. 2020).

\subsection{Data analysis}

Cross-shore differences in larval assemblages were visualized using non-metric multidimensional scaling (NMDS) and tested using permutational multivariate ANOVA (PERMANOVA) ('adonis' function, 9999 permutations, $\mathrm{R}$ version 3.5.0). To determine which taxa contributed to cross-shore differences in larval assemblages, similarity percentages were calculated using SIMPER analyses (Clarke \& Warwick 2001). NMDS, PERMANOVA, and SIMPER were run in $\mathrm{R}$ with the package 'vegan' ( $\mathrm{R}$ version 3.5.0; Oksanen et al. 2018).

Relationships between abundances of larval taxa and cross-shore distance and environmental parameters (salinity, water temperature, depth, and chl a) were analyzed using general linear zero-inflated negative binomial models (with log link) or negative binomial models (when larval abundance did not have excess zeros), because larval abundances of each taxon were heavily skewed toward zero. In the case where there was one very high abundance value (e.g. Cirripedia postlarvae), we tested model results with and without the potential outlier and included the value if the model results were similar. Model selection was conducted using the Vuong test in R (Vuong 1989). Individual models were run for all environmental predictors within each month using the 'pscl' (Jackman 2020) and 'MASS' (Venables \& Ripley 2002) packages in R. Since cross-shore distance was an ordered categorical variable, the model with cross-shore distance was compared to the null model and if significant, post hoc Tukey HSD tests were run to determine which cross-shore distances were significantly different from each other (package 'multcomp,' Hothorn et al. 2008). Since depth, water temperature, salinity, and chl a concentration were continuous variables, significance results are reported from model output. Two metrics for depth preference were used, namely distance from the seafloor and distance from the surface, because larvae that associate with the bottom may show a strong relationship with distance from the seafloor, whereas larvae that associate with the surface may show a strong relationship with depth or distance from the surface. Nearly all larvae were associated with distance from the seafloor, so results and figures display distance from the seafloor as the depth metric.

\section{RESULTS}

\subsection{Cross-shore variation in ocean conditions}

The temperature profile of the August sampling period was characterized by strong thermal stratification along the entire transect, with warmer water occurring nearshore (Fig. 2). In August, the water temperature range was $11-15^{\circ} \mathrm{C}$, and the thermocline occurred at about $10 \mathrm{~m}$ depth. In October, warmer water still occurred nearshore, but temperatures were cooler and spanned a smaller range (11$13^{\circ} \mathrm{C}$ ), and the water column was less stratified than in August (Fig. 2). In August, salinity was vertically stratified along the length of the entire transect, and values were higher than in October. October was characterized by low salinity water intruding from offshore, as evidenced by vertical isohalines extending from the bottom to the surface near the offshore station (Fig. 2). In August, chl a concentrations peaked in the middle (outer bay and mid bay) to bottom (inner bay) of the water column $(\sim 5-15 \mathrm{~m}$ depths) throughout the transect. In October, the area of high chl a concentration was near the surface ( 0-8 $\mathrm{m}$ depth) and had lower maximum concentrations (Fig. 2). 

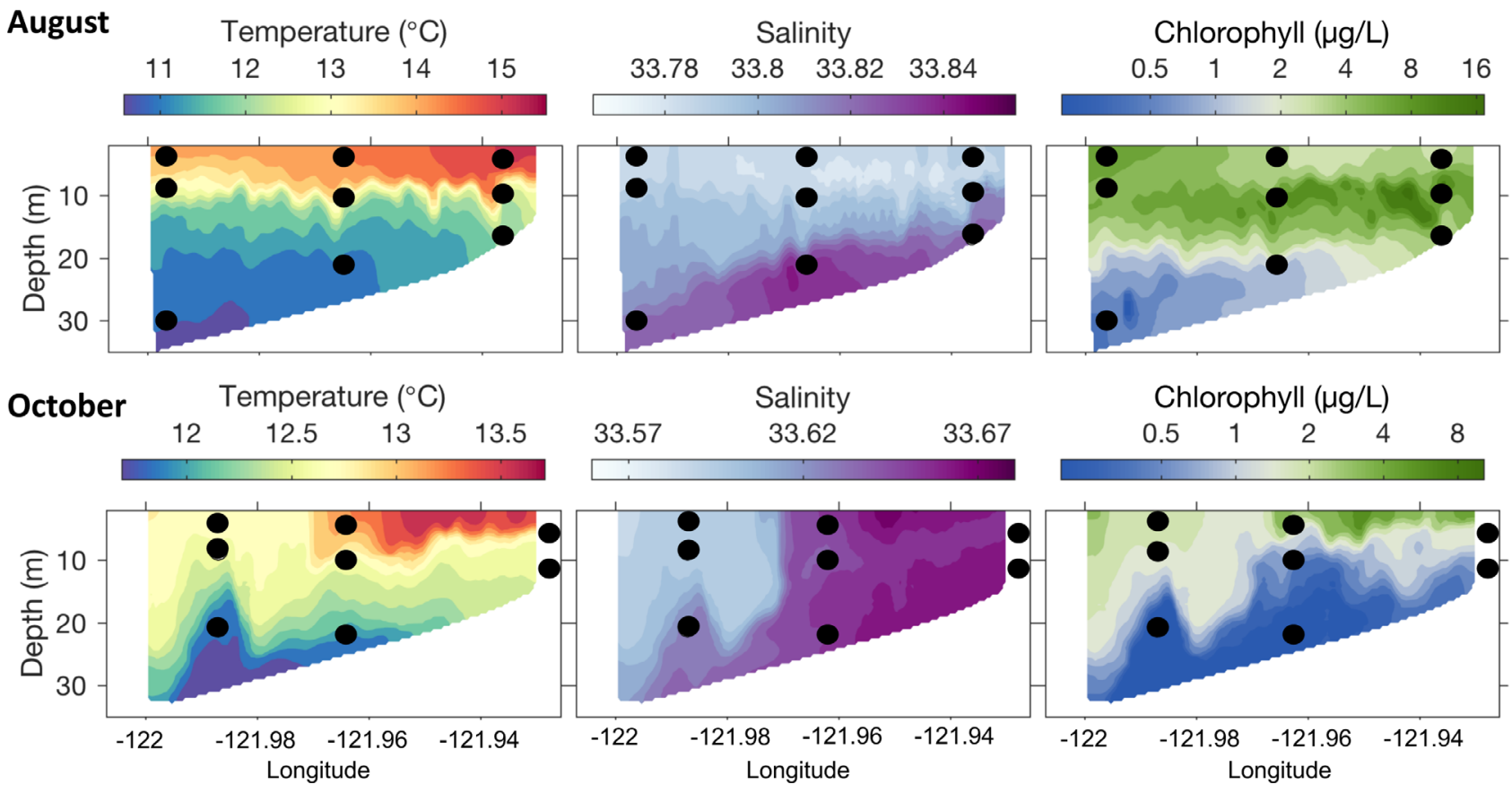

Fig. 2. Representative vertical sections of temperature, salinity, and chlorophyll a concentration from AUV 'Dorado' surveys along the northern Monterey Bay sampling transect from the first day of sampling in August (12 August 2013) and October (22 October 2013). The sections represent general ocean conditions during each cruise. Transect endpoints are the farthest offshore and onshore locations of the ship sampling locations shown in Fig. 1b. Black circles represent the sampling depths at each station. The scales for the variables depicted are different for August and October since the range of the variables changed considerably between the 2 sampling periods. For plots of all sampling days in August and October, refer to Satterthwaite et al. (2020)

\subsection{Benthic invertebrate larval abundance}

Eleven broad taxa were present in samples from northern Monterey Bay in August and October 2013 (Table 1). Of those, Bivalvia, Gastropoda, Echinoidea, Polychaeta, Cirripedia, Anomura, Gymnolaemata, Gebiidea, and Brachyura consisted of species generally found in the nearshore, intertidal zone, or were widespread, and Ophiuroidea and Brachiopoda consisted of species generally found deep and offshore or were widespread (Table 1).

\subsubsection{Cross-shore distance}

Larval assemblages of benthic invertebrates differed with distance from shore in October (PERMANOVA, $\left.F_{2,29}=3.50, \mathrm{R}^{2}=0.19, \mathrm{p}<0.001\right)$, but not in August $\left(F_{2,41}=1.11, \mathrm{R}^{2}=0.05, \mathrm{p}=0.31\right)$ (Fig. 3). According to the SIMPER analysis, Polychaeta late larvae and postlarvae, Bivalvia postlarvae, and Ophiuroidea early and late larvae contributed the most to differences in larval assemblages among the inner, mid, and outer bay.
Developmental stages of 5 nearshore taxa were more abundant nearshore $(4 \mathrm{~km})$ in August: Polychaeta late larvae and postlarvae, Bivalvia postlarvae, Gymnolaemata early larvae, Cirripedia early and postlarvae, and Brachyura early larvae (Table 2, Fig. 4a). A few of these taxa, namely Polychaeta late larvae, Polychaeta postlarvae, and Cirripedia postlarvae, were also found in higher abundances nearshore in October (Table 2, Fig. 4a). Offshore taxa, namely Brachiopoda and Ophiuroidea, occurred in higher abundances in the outer bay $(12 \mathrm{~km})$ in October, and Ophiuroidea early larvae displayed a similar pattern in August (Table 2, Fig. 4b).

\subsubsection{Depth}

Most developmental stages of nearshore taxa occurred in higher abundances close to the bottom in August (Table 2; see Fig. S1a in the Supplement at www.int-res.com/articles/suppl/m661p035_supp.pdf). This pattern held in October for Polychaeta late larvae and postlarvae and Cirripedia postlarvae (Table 2, Fig. S1a). Larval stages of offshore taxa, such as Bra- 
Table 1. Species within 11 broad taxa collected from northern Monterey Bay in August and October 2013 identified by genetic (in bold font) or morphological analyses with the common adult habitat distribution for each taxon (Carleton 2007). Taxa that were present within each month are denoted by an ' $X_{1}$ ' and species are ordered by abundance within each taxon when morphological analyses were used

\begin{tabular}{|c|c|c|c|}
\hline \multirow{2}{*}{ Taxon } & \multirow{2}{*}{$\begin{array}{l}\text { Adult habitat } \\
\text { distribution }\end{array}$} & \multicolumn{2}{|c|}{ — Presence - } \\
\hline & & August & October \\
\hline \multicolumn{4}{|l|}{ Bivalvia (bivalves) } \\
\hline Kellia suborbicularis & Nearshore (intertidal) & $\mathrm{X}$ & $\mathrm{X}$ \\
\hline Clinocardium nuttallii & Widespread & $\mathrm{X}$ & $\mathrm{X}$ \\
\hline \multicolumn{4}{|l|}{ Gastropoda (snails) } \\
\hline Amphissa reticulata & Nearshore (intertidal) & $\mathrm{X}$ & $\mathrm{X}$ \\
\hline Crepipatella lingulata & Widespread & $\mathrm{X}$ & $\mathrm{X}$ \\
\hline Amphissa columbiana & Nearshore (intertidal) & $\mathrm{X}$ & $\mathrm{X}$ \\
\hline Epitonium sawinae & Nearshore & $\mathrm{X}$ & $\mathrm{X}$ \\
\hline Mitrella tuberosa & Nearshore & $\mathrm{X}$ & \\
\hline Olivella biplicata & Nearshore (intertidal) & $\mathrm{X}$ & \\
\hline Nassarius mendicus & Nearshore (intertidal) & $\mathrm{X}$ & \\
\hline Tegula pulligo & Nearshore & & $\mathrm{X}$ \\
\hline Gastropteron pacificum & Widespread & $\mathrm{X}$ & \\
\hline \multicolumn{4}{|l|}{ Ophiuroidea (brittle stars) } \\
\hline Amphiodia urtica & Offshore & $\mathrm{X}$ & $\mathrm{X}$ \\
\hline Ophiopholis kennerlyi & Widespread & $\mathrm{X}$ & $\mathrm{X}$ \\
\hline Amphipholis sp. & Widespread & $\mathrm{X}$ & \\
\hline Ophiopteris papillosa & Widespread & & $\mathrm{X}$ \\
\hline \multicolumn{4}{|l|}{ Echinoidea (sea urchins) } \\
\hline Strongylocentrotus sp. & Widespread & $\mathrm{X}$ & $\mathrm{X}$ \\
\hline \multicolumn{4}{|l|}{ Polychaeta (worms) } \\
\hline Phragmatopoma californica & Nearshore & $\mathrm{X}$ & $\mathrm{X}$ \\
\hline Pholoides asperus & Nearshore (intertidal) & $\mathrm{X}$ & $\mathrm{X}$ \\
\hline Phyllodoce medipapillata & Widespread & $\mathrm{X}$ & $\mathrm{X}$ \\
\hline Halosydna brevisetosa & Widespread & $\mathrm{X}$ & $\mathrm{X}$ \\
\hline Micropodarke dubia & Nearshore (intertidal) & $\mathrm{X}$ & $\mathrm{X}$ \\
\hline Lepidasthenia berkeleyae & Widespread & $\mathrm{X}$ & \\
\hline Bipalponephtys cornuta & Widespread & $\mathrm{X}$ & $\mathrm{X}$ \\
\hline Eulalia aviculiseta & Nearshore & $\mathrm{X}$ & $\mathrm{X}$ \\
\hline Glycera sp. & Widespread & $\mathrm{X}$ & \\
\hline Diopatra ornata & Nearshore (intertidal) & & $\mathrm{X}$ \\
\hline Chaetopterus sp. & Nearshore & & $\mathrm{X}$ \\
\hline \multicolumn{4}{|l|}{ Cirripedia (barnacles) } \\
\hline Balanus crenatus & Nearshore & $\mathrm{X}$ & $\mathrm{X}$ \\
\hline Pollicipes polymerus & Nearshore (intertidal) & $\mathrm{X}$ & $\mathrm{X}$ \\
\hline Balanus nubilus & Nearshore (intertidal) & $\mathrm{X}$ & $\mathrm{X}$ \\
\hline Chthamalus dalli & Nearshore (intertidal) & $\mathrm{X}$ & $\mathrm{X}$ \\
\hline Semibalanus cariosus & Nearshore (intertidal) & $\mathrm{X}$ & \\
\hline Balanus glandula & Nearshore (intertidal) & $\mathrm{X}$ & $\mathrm{X}$ \\
\hline \multicolumn{4}{|l|}{ Anomura (anomuran crabs) } \\
\hline Emerita analoga & Nearshore (intertidal) & $\mathrm{X}$ & $\mathrm{X}$ \\
\hline Petrolisthes sp. & Nearshore (intertidal) & & \\
\hline \multicolumn{4}{|l|}{ Brachiopoda (brachiopods) } \\
\hline Brachiopoda & Widespread & $\mathrm{X}$ & $\mathrm{X}$ \\
\hline \multicolumn{4}{|l|}{ Gymnolaemata (bryozoans) } \\
\hline Membranipora membranacea & Nearshore & $\mathrm{X}$ & $\mathrm{X}$ \\
\hline \multicolumn{4}{|l|}{ Gebiidea (mud shrimp) } \\
\hline Upogebia pugettensis & Nearshore (intertidal) & $\mathrm{X}$ & $\mathrm{X}$ \\
\hline \multicolumn{4}{|l|}{ Brachyura (true crabs) } \\
\hline Pinnotheridae (Pinnixa faba) & Nearshore & $\mathrm{X}$ & $\mathrm{X}$ \\
\hline $\begin{array}{l}\text { Cancridae (C. gracilis, } \\
R \text {. antennarium) }\end{array}$ & Widespread & $\mathrm{X}$ & $\mathrm{X}$ \\
\hline Hemigrapsus nudus & Nearshore (intertidal) & $\mathrm{X}$ & $\mathrm{X}$ \\
\hline Lophopanopeus bellus & Nearshore (intertidal) & $\mathrm{X}$ & \\
\hline Majidae (Scyra acutifrons) & Nearshore (intertidal) & $\mathrm{X}$ & $\mathrm{X}$ \\
\hline Metacarcinus magister & Nearshore & $\mathrm{X}$ & \\
\hline
\end{tabular}

chiopoda and Ophiuroidea, showed a similar, although non-significant, pattern related to depth (Table 2, Fig. S1b).

\subsubsection{Water types and chl a concentration}

Water types were characterized by variation in temperature and salinity in August and October (Fig. 2). Of the nearshore taxa, Cirripedia postlarvae were found in higher abundances in warmer water in August, and the early larvae of Cirripedia and Anomura trended toward this pattern (Table 2, Fig. S2a). Polychaeta late larvae and postlarvae, Cirripedia postlarvae, Brachyura early larvae, and Echinoidea postlarvae were found in higher abundances in relatively saltier water in $\mathrm{Oc}$ tober (Table 2, Fig. S3a). Larval stages of offshore taxa were related to water characteristics in both months. Specifically, larval stages of Brachiopoda and Ophiuroidea were more likely to occur in cooler water temperatures in August (Table 2, Fig. S2b), and in fresher water in October (Table 2, Fig. S3b).

Both nearshore and offshore taxa occurred in higher abundances in areas of high chl a concentration in August (Table 2, Fig. S4a,b). No taxa were positively related to chl a concentration in October (Table 2).

\subsubsection{Associations among larval taxa}

Developmental stages of all nearshore taxa were positively correlated with each other (Table 3, Fig. 5), including larval stages of Polychaeta, Gastropoda, Bivalvia, Gymnolaemata, Cirripedia, Anomura, Brachyura, and Echinoidea. Similarly, larval stages of offshore taxa (Brachiopoda and Ophiuroidea) were positively correlated with each other (Table 3, Fig. 5). Early, late, and postlarval stages cooccurred in samples for Polychaeta and Cirripedia. 


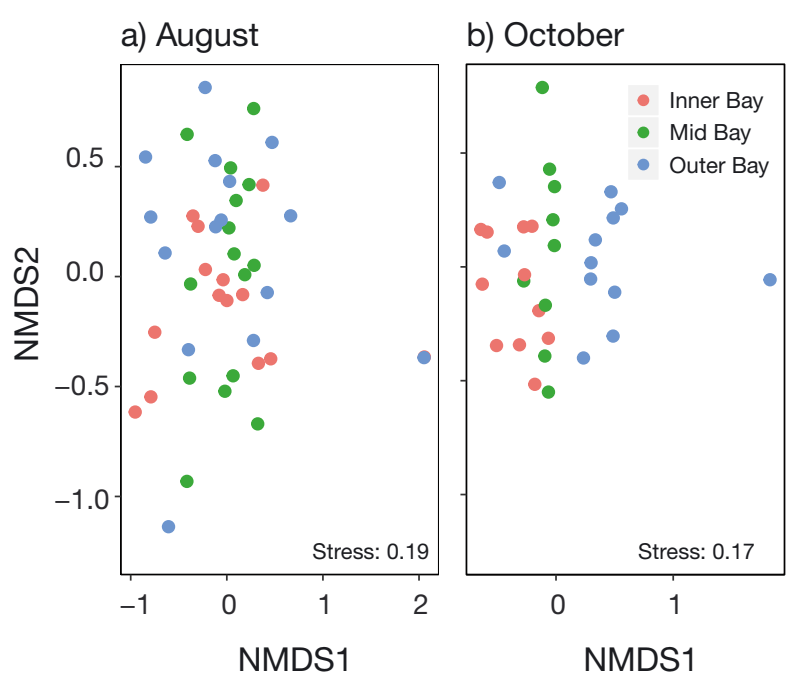

Fig. 3. Nonmetric multidimensional scaling of cross-shore larval assemblages in northern Monterey Bay in (a) August and (b) October 2013: inner bay (4 km from shore), mid-bay (8 $\mathrm{km}$ from shore), outer bay (12 km from shore). Stress values are reported in the lower right corner of each plot

\section{DISCUSSION}

\subsection{Larval supply and retention in the upwelling shadow}

Larval abundances in Monterey Bay differed considerably cross-shore and with depth. Higher larval abundances of many nearshore taxa occurred in the upwelling shadow compared to farther offshore in August, consistent with previous studies in both Monterey Bay (Graham et al. 1992, Graham \& Largier 1997) and other upwelling shadows in the lee of coastal headlands (Wing et al. 1998, Roughan et al. 2005, Mace \& Morgan 2006, Morgan \& Fisher 2010, Morgan et al. 2011b, Hameed et al. 2018). This trend persisted in October despite different oceanic conditions. Conversely, offshore taxa, such as Brachiopoda and Ophiuroidea, occurred in the outer bay in both months, likely because adults released larvae from deeper shelf water that subsequently entered Monterey Bay. In addition, both nearshore and offshore taxa tended to occur close to the bottom in both months, yet this relationship was significant for more taxa in August than in October.

Depth distributions are likely explained by vertical positioning of larvae in the water column and food availability. Many larvae regulate depth in stratified currents, reducing offshore and alongshore transport by avoiding the surface Ekman layer and staying in slower bottom currents (Morgan et al. 2009a, 2018, Shanks \& Shearman 2009, Morgan \& Fisher 2010,
Miller \& Morgan 2013). Larvae of many abundant nearshore taxa collected during our study (i.e. Bivalvia, Polychaeta, Cirripedia, and Brachyura) tended to be uncommon in the surface layer and more abundant deeper in the water column during both months, a condition that may be instrumental in their nearshore retention.

In addition, larvae of many taxa were positively related to chl a concentration in August but not in October. Phytoplankton accumulation occurred at the thermocline in August, as has been previously described for northern Monterey Bay (McManus et al. 2008, Ryan et al. 2010b). Although weakly swimming larvae can passively concentrate at thermoclines, they typically swim across realistic thermoclines in the laboratory (Young 1995, Morgan 2020). Larvae, especially late stages of strongly-swimming taxa, may have aggregated to forage on high concentrations of phytoplankton (Lasker 1975, Woodson \& McManus 2007). For example, early larval stages of Cirripedia, Polychaeta, Gastropoda, and Bivalvia eat phytoplankton (Fauchald \& Jumars 1979, Turner et al. 2001, Vargas et al. 2006) and may have foraged in areas of high chl a concentration during August. Cirripedia postlarvae were also related to elevated chl a in August, but they are non-feeding (Strathmann 1985).

Since elevated chl a concentrations can be associated with convergence zones (Ryan et al. 2014b), and Cirripedia postlarvae (cyprids) swim upward to counter downwelling velocities characteristic of convergence zones (DiBacco et al. 2011), the combination of sinking and swimming behavior exhibited by Cirripedia postlarvae may have enhanced their concentration in the nearshore convergence zone in August. Barnacle (Shanks \& Wright 1987, Pineda 1991) and fish postlarvae (Phelan et al. 2018) are transported shoreward in the convergence zone by internal waves, which commonly occur in Monterey Bay (Walter et al. 2012).

More taxa were abundant closer to the bottom in August, which could have been, in part, due to the subsurface location of high chl a concentrations. In August, chl a concentrations were higher and closer to the bottom ( 8-15 $\mathrm{m}$ depth) than in October. This was especially true nearshore where larvae tended to be concentrated. Conversely, chl a values were much lower and chl a was concentrated near the surface ( 0-7 $\mathrm{m}$ depth) in October. Larvae may have occurred below surface chl a layers in October either because the phytoplankton concentrations were too low to stimulate larval feeding, as has been observed for anchovy larvae (Lasker 1975), or because larvae 


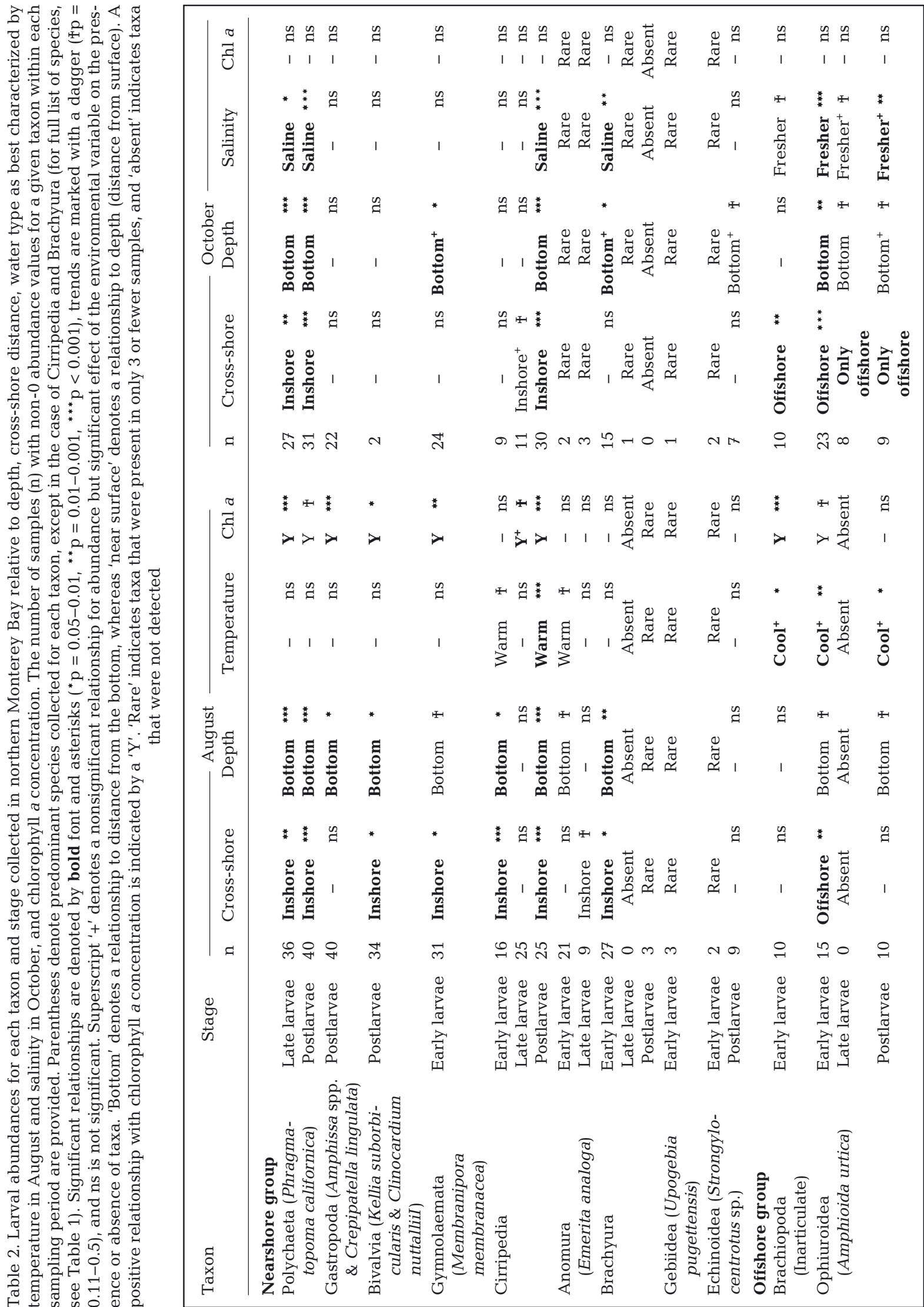



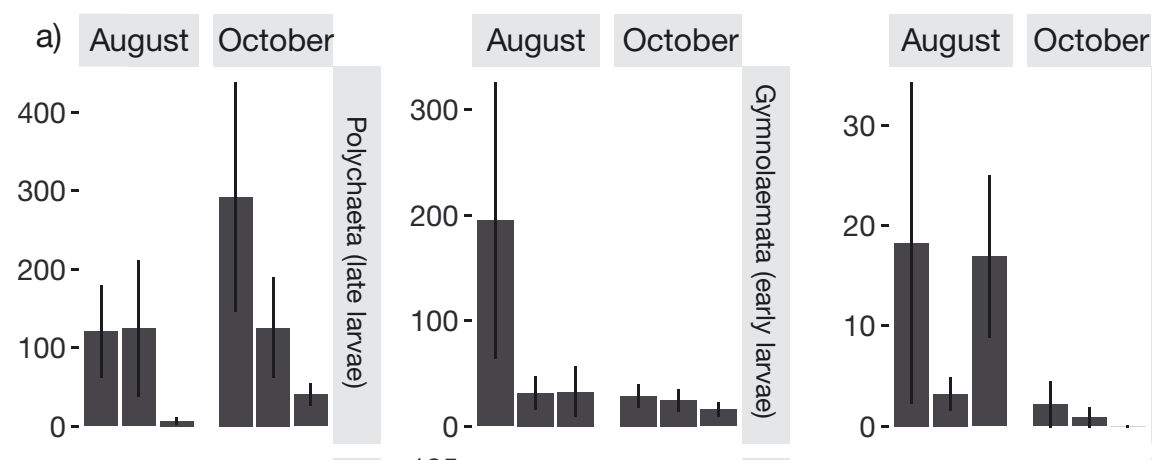

b) August October
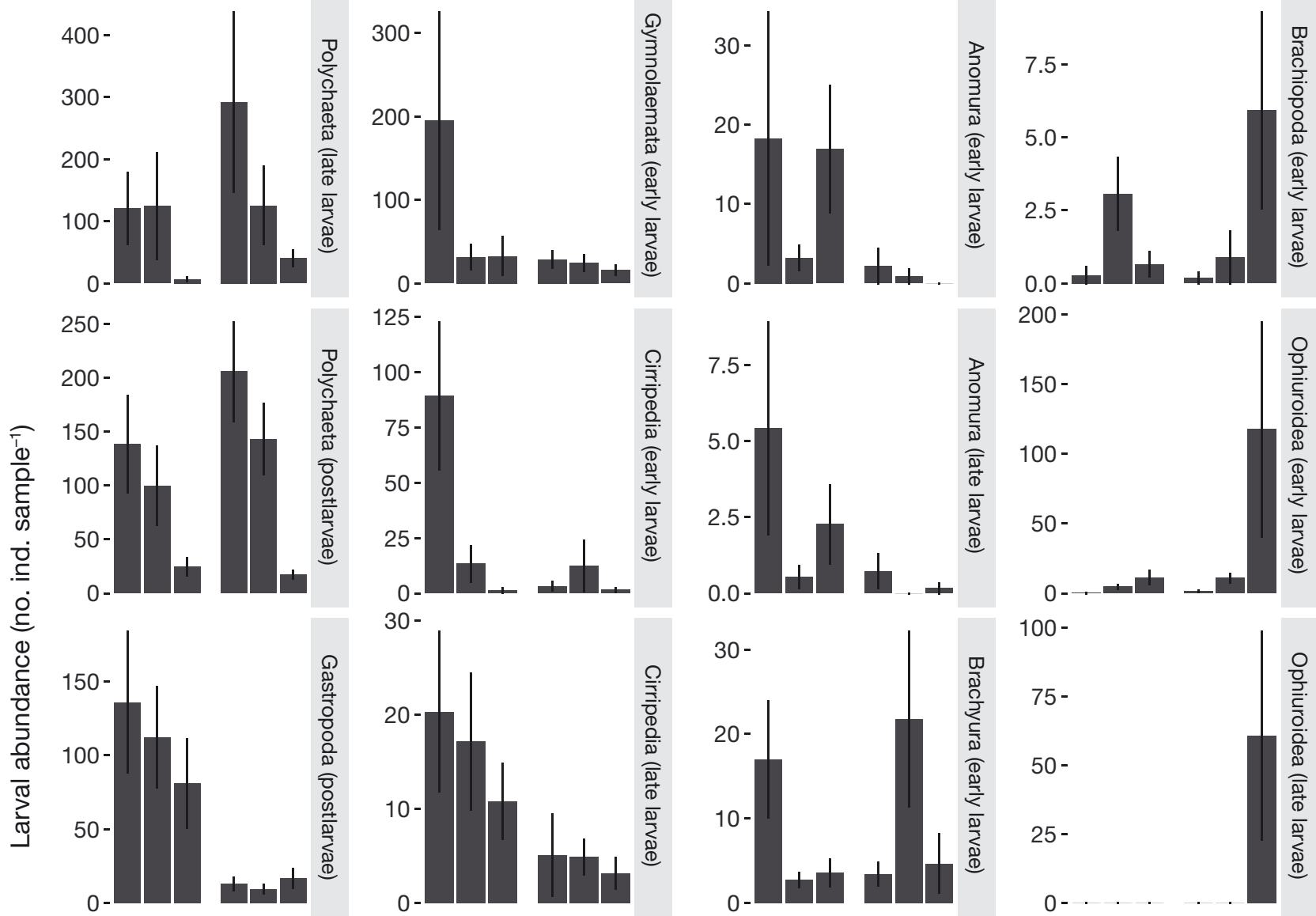

200 -

$150-$

$100-$

$$
30-
$$
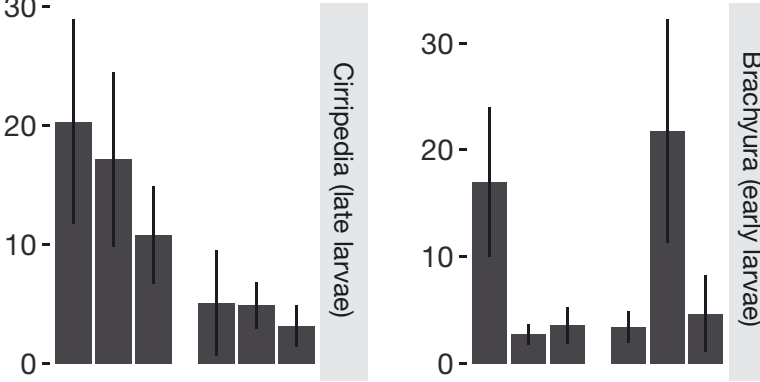

50 .

$50-$

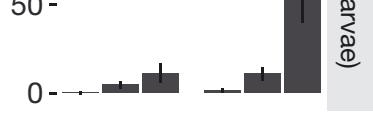

$100-$
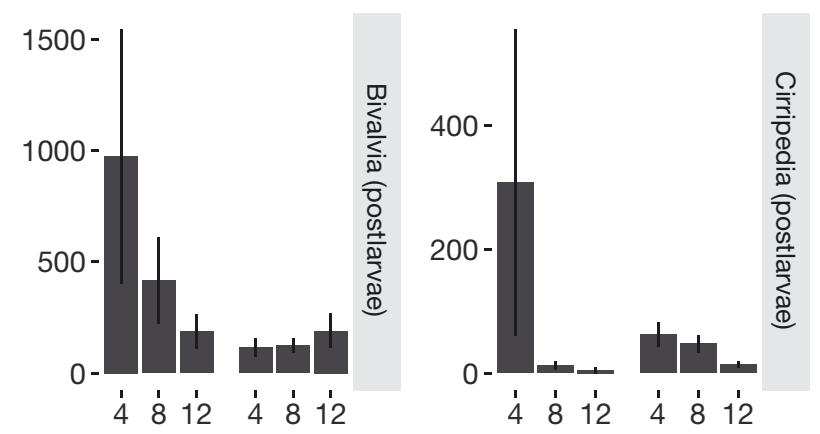

$10.0-$

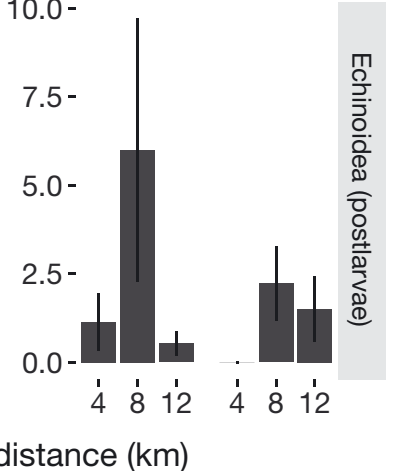

75

$50-$

$25-$

0

50 -

$40-$

$30-$

20 -

10 -

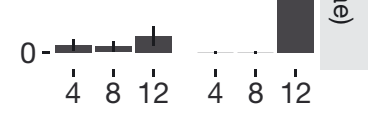

Fig. 4. Mean \pm SE abundances of developmental stages for 10 taxa collected from northern Monterey Bay in 2013 by crossshore distance in August and October. Plots are grouped by (a) taxa that tended to be more abundant in August and are predominately nearshore taxa and (b) those that tended to be more abundant in October and are predominately offshore taxa. Taxa that were absent or rare across both sampling periods ( 3 or fewer samples with non-0 abundances within a sampling period) are not displayed. Refer to Table 2 for significance values and for absent and rare taxa

of many species avoid the neuston (Morgan \& Fisher 2010).

Larvae of offshore taxa appeared to be associated with different water types in both August and October, as indicated by relationships to seawater temperature and salinity. In August, offshore taxa were associated with cold, upwelled, offshore water entering the study area. In October, offshore taxa were associated with the lower salinity water that was influenced by influx from the California Current. For example, Brachiopoda and Ophiuroidea larvae tended to be associated with cold offshore water 


\begin{tabular}{|c|c|c|c|c|c|c|c|c|c|c|c|c|c|c|c|c|}
\hline 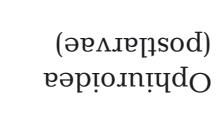 & $\begin{array}{l}n \\
a \\
\vdots \\
0\end{array}$ & $\begin{array}{l}* \\
\dddot{\rho} \\
\stackrel{1}{1}\end{array}$ & $\begin{array}{l}\tilde{a} \\
\stackrel{1}{a} \\
\stackrel{0}{0}\end{array}$ & $\begin{array}{l}n \\
a \\
n \\
0 \\
0\end{array}$ & $\begin{array}{l}\text { a } \\
\overrightarrow{0} \\
\dot{1}\end{array}$ & $\begin{array}{l}n \\
\check{a} \\
\tilde{O} \\
0 \\
0\end{array}$ & $\begin{array}{c}n \\
a \\
\ddot{0} \\
1\end{array}$ & $\begin{array}{c}n \\
a \\
\overrightarrow{0} \\
i\end{array}$ & $\begin{array}{l}n \\
\Xi \\
0 \\
0\end{array}$ & \begin{tabular}{l}
$\tilde{a}$ \\
\multirow{1}{*}{} \\
$\tilde{o}$ \\
$\dot{0}$
\end{tabular} & $\begin{array}{l}\tilde{y} \\
q \\
0 \\
0 \\
0\end{array}$ & $\begin{array}{l}n \\
a \\
m \\
\stackrel{0}{0}\end{array}$ & $\begin{array}{l}* \\
\stackrel{*}{*} \\
\stackrel{8}{0}\end{array}$ & \begin{tabular}{l}
$*$ \\
\multirow{2}{*}{} \\
$\stackrel{0}{0}$
\end{tabular} & $\begin{array}{l}* \\
\vdots \\
8 \\
8 \\
0\end{array}$ & $\begin{array}{l}1 \\
-1\end{array}$ \\
\hline (әеАлЕ әңЕ) & q & द & 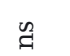 & $气$ & $g$ & 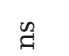 & 气 & 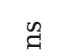 & 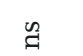 & 气 & 气 & g & $*$ & 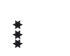 & 1 & $\#$ \\
\hline eәрțo.n!̣udo & $\stackrel{1}{7}$ & $\begin{array}{l}N \\
0 \\
1\end{array}$ & $\ddot{i}$ & $\overrightarrow{7}$ & $\underset{0}{1}$ & 0 & $\overrightarrow{0}$ & $\stackrel{2}{0}$ & $\begin{array}{l}n \\
0 \\
1\end{array}$ & i & $\overrightarrow{0}$ & $\stackrel{n}{?}$ & $\stackrel{n}{0}$ & $\stackrel{\infty}{+}$ & - & مृ \\
\hline (әемлте & $气$ & 气 & ๕ & * & a & $气$ & g & 气 & 气 & a & g & 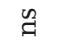 & 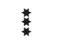 & 1 & 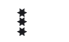 & * \\
\hline eәpṭo.n!̣udo & $\stackrel{\sim}{0}$ & $\stackrel{2}{0}$ & $\stackrel{\sharp}{\stackrel{4}{0}}$ & $\stackrel{\infty}{\dddot{\theta}}$ & $\ddot{0}$ & i & $\begin{array}{l}\infty \\
0 \\
0\end{array}$ & สู & $\stackrel{m}{0}$ & $\ddot{i}$ & i & $\stackrel{\sim}{0}$ & $\stackrel{\Re}{0}$ & - & $\stackrel{\infty}{\stackrel{+}{0}}$ & ๗ึ. \\
\hline 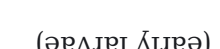 & ? & ב & 气 & $\stackrel{n}{a}$ & ב & ב & $*$ & z & ? & 气 & ב & ב & 1 & $*$ & $*$ & $*$ \\
\hline 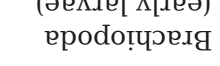 & $\stackrel{\sim}{0}$ & i & $\vec{z}$ & $\stackrel{\infty}{\stackrel{0}{0}}$ & $\ddot{0}$ & $\begin{array}{l}0^{\prime} \\
0\end{array}$ & 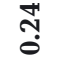 & i & i & $\vec{i}$ & $\vec{i}$ & $\stackrel{?}{?}$ & - & $\stackrel{?}{\stackrel{9}{0}}$ & $\stackrel{\mathscr{c}}{\tilde{0}}$ & స్ํ \\
\hline & q & 气ै & ב & $\mathscr{q}$ & $*$ & ב & * & $\mathscr{z}$ & द & a & z & I & $\tilde{q}$ & 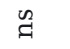 & 气 & ? \\
\hline 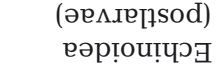 & $\stackrel{-1}{0}$ & i & $\stackrel{1}{\stackrel{1}{0}}$ & $\stackrel{m}{0}$ & $\stackrel{n}{\dddot{0}}$ & $\stackrel{\sharp}{\leftrightarrows}$ & $\stackrel{\infty}{\sim}$ & $\stackrel{\infty}{\circ}$ & $\ddot{0}$ & $\ddot{i}$ & i & - & $\stackrel{9}{-1}$ & ָ̃ & $\stackrel{n}{\rightarrow}$ & $\stackrel{m}{-}$ \\
\hline & $*$ & * & * & $\stackrel{a}{a}$ & ? & 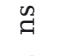 & 气 & $*$ & $*$ & * & 1 & 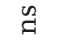 & 气 & $\cong$ & 气 & 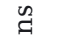 \\
\hline 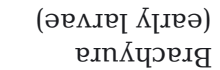 & ஜூ̊ & $\stackrel{\mathscr{N}}{0}$ & $\stackrel{\overbrace{}}{0}$ & $\stackrel{\infty}{\stackrel{1}{0}}$ & $\underset{0}{ت}$ & 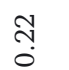 & $\stackrel{N}{\stackrel{N}{0}}$ & $\stackrel{\mathscr{m}}{0}$ & Ðే & $\stackrel{\mathscr{N}}{\mathscr{O}}$ & - & i & $\overrightarrow{0}$ & i & in & 今. \\
\hline & ? & 气 & ‡ & $\mathscr{q}$ & $*$ & $\stackrel{q}{q}$ & q & 气 & द्व & I & * & 气 & q & 气 & 气 & ב \\
\hline 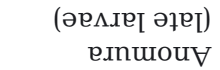 & $\vec{i}$ & $\begin{array}{l}N \\
0 \\
1\end{array}$ & o & $\mathfrak{i}_{i}$ & $\dddot{m}_{i}^{0}$ & i & $\begin{array}{l}N \\
0 \\
1\end{array}$ & $\mathfrak{o}_{1}^{1}$ & $\overrightarrow{0}$ & - & $\stackrel{\leftrightarrow}{0}$ & $\vec{i}$ & $\overrightarrow{0}$ & $\vec{i}$ & i & $\underset{0}{0}$ \\
\hline & ? & ב & $\#$ & * & $*$ & ? & $*$ & q & 1 & z & $*$ & ? & q & ב & q & ב \\
\hline 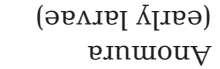 & $\stackrel{n}{0}$ & స̃ & กิ & 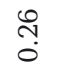 & ঙ্ণ & $\stackrel{m}{\circ}$ & $\stackrel{n}{0}$ & $\stackrel{1}{3}$ & - & $\overrightarrow{0}$ & ఊே & $\begin{array}{l}0 \\
0 \\
0\end{array}$ & i & $\stackrel{m}{:}$ & $\begin{array}{l}N \\
i \\
i\end{array}$ & $\stackrel{8}{0}$ \\
\hline & 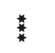 & $*$ & * & $*$ & $*$ & $*$ & $*$ & 1 & a & a & * & a & q & a & a & a \\
\hline 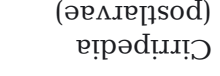 & $\stackrel{\pi}{0}$ & $\stackrel{8}{0}$ & กั & $\stackrel{\text { Ṭ }}{0}$ & $\stackrel{\sharp}{:}$ & $\stackrel{+}{0}$ & $\stackrel{m}{0}$ & - & $\stackrel{7}{:}$ & $\begin{array}{c}\text { No } \\
\vdots \\
\end{array}$ & $\stackrel{\mathscr{m}}{0}$ & $\stackrel{\infty}{\circ}$ & i & สิ & $\ddot{0}$ & $\vec{i}$ \\
\hline & $*$ & $\#$ & $\#$ & $\#$ & $*$ & $*$ & I & * & * & ב & q & * & * & q & q & ? \\
\hline 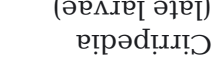 & $\stackrel{\tilde{\overbrace{}}}{0}$ & †ै & $\stackrel{18}{7}$ & $\stackrel{7}{7}$ & $\stackrel{\infty}{\stackrel{\infty}{0}}$ & : & $\dashv$ & $\dddot{0}$ & 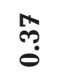 & ĩ & $\stackrel{+}{0}$ & 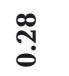 & $\stackrel{ت}{\check{S}}$ & $\stackrel{\infty}{0}$ & $\overrightarrow{0}$ & $\vec{i}$ \\
\hline 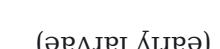 & $*$ & $*$ & $*$ & $*$ & $*$ & 1 & * & $*$ & दे & ? & 气 & 气 & $\check{q}$ & ב & g & ? \\
\hline 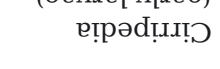 & $\underset{0}{7 !}$ & $\stackrel{+}{\stackrel{n}{0}}$ & $\stackrel{n}{\tilde{\theta}}$ & $\stackrel{n}{3}$ & $\stackrel{\leftrightarrow}{0}$ & - & $\stackrel{i b}{0}$ & $\stackrel{\ddot{0}}{0}$ & $\stackrel{m}{0}$ & i & สู & $\stackrel{\sharp}{\stackrel{H}{0}}$ & $\begin{array}{l}\text { Uे } \\
0\end{array}$ & i & 0 & $\stackrel{m}{0}$ \\
\hline (әемлет Кโлеә) & $*$ & $*$ & $*$ & * & I & 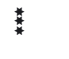 & $\#$ & $*$ & $*$ & * & 气 & $*$ & q & $\stackrel{2}{a}$ & द & $a$ \\
\hline еұешәегоиш & 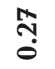 & $\stackrel{?}{\because}$ & ஜூ & 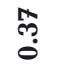 & - & $\stackrel{\leftrightarrow}{!}$ & $\stackrel{\infty}{\stackrel{\infty}{0}}$ & $\stackrel{\sharp}{\sharp !}$ & $\stackrel{\text { शु }}{i}$ & $\ddot{\rho}_{i}$ & $\underset{0}{ت}$ & $\stackrel{n}{0}$ & $\overrightarrow{0}$ & $\stackrel{n}{0}$ & $\begin{array}{l}0 \\
0 \\
0\end{array}$ & $\ddot{0}$ \\
\hline (әемле[१sod) & $*$ & $*$ & $*$ & 1 & $*$ & $*$ & $*$ & $*$ & * & q & 气 & 气 & 气 & $*$ & 气 & 气 \\
\hline ए!̣ & : & i̊ & $\stackrel{1}{\ell}$ & - & $\stackrel{n}{\tilde{\rho}}$ & $\stackrel{5}{9}$ & $\underset{7}{7}$ & $\stackrel{?}{+}$ & స్ํ & $\begin{array}{l}1 \\
i \\
i\end{array}$ & $\stackrel{\infty}{:}$ & $\stackrel{m}{:}$ & $\stackrel{\infty}{-1}$ & $\stackrel{n}{0}$ & $\overrightarrow{7}$ & $\stackrel{1}{0}$ \\
\hline (әеАле[ұsod) & $*$ & * & 1 & 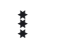 & $*$ & $*$ & $*$ & * & $*$ & a & * & a & a & $g$ & a & ? \\
\hline epodo.lpsey & $\stackrel{\mathscr{\overbrace}}{\dddot{0}}$ & $\stackrel{n}{0}$ & - & $\stackrel{8}{0}$ & ஜூ & $\stackrel{n}{0}$ & $\stackrel{1}{4}$ & $\stackrel{\mathscr{N}}{0}$ & กै & ○ & 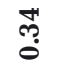 & $\stackrel{1}{\div}$ & $\underset{-1}{ت}$ & $\stackrel{\sharp}{:}$ & $\ddot{i}$ & $\stackrel{7}{7}$ \\
\hline (әецле[]SOd) & $\#$ & 1 & * & $\#$ & 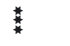 & $*$ & $\#$ & $\$$ & 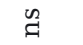 & 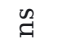 & * & $q$ & g & 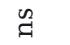 & $q$ & * \\
\hline еұәецЈК $\mathrm{LO}_{\mathrm{d}}$ & ְै & - & $\stackrel{n}{0}$ & $\underset{\substack{0 \\
0}}{\substack{0 \\
0}}$ & $\stackrel{?}{+}$ & $\stackrel{n}{0}$ & $\stackrel{\text { I̦ }}{0}$ & $\stackrel{8}{\stackrel{\theta}{0}}$ & $\underset{\text { స̦ }}{0}$ & ơ & 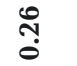 & i & i & $\stackrel{n}{0}$ & $\tilde{o}_{1}^{N}$ & $\dddot{i}_{i}^{n}$ \\
\hline 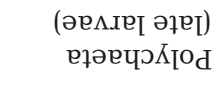 & $\begin{array}{c}1 \\
-1\end{array}$ & $\begin{array}{l}\stackrel{*}{*} \\
\stackrel{*}{్} \\
\stackrel{0}{0}\end{array}$ & \begin{tabular}{l}
$*$ \\
\multirow{2}{*}{} \\
$\stackrel{0}{0}$ \\
0
\end{tabular} & $\begin{array}{l}0 \\
0 \\
0 \\
0 \\
0 \\
0\end{array}$ & 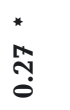 & $\begin{array}{l}\stackrel{*}{*} \\
\stackrel{7}{0}\end{array}$ & $\begin{array}{l}* \\
\text { Ñ } \\
\tilde{O} \\
0\end{array}$ & $\begin{array}{l}\stackrel{*}{*} \\
\text { तै } \\
\stackrel{0}{0}\end{array}$ & 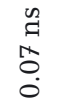 & $\begin{array}{l}\text { a } \\
\stackrel{-1}{0} \\
\stackrel{0}{1}\end{array}$ & $\begin{array}{l}* \\
0 \\
0 \\
0 \\
0\end{array}$ & $\begin{array}{l}n \\
\vdots \\
0 \\
0 \\
0\end{array}$ & 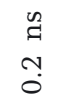 & \begin{tabular}{l} 
a \\
\multirow{1}{*}{} \\
$\tilde{o}$
\end{tabular} & $\begin{array}{l}n \\
\stackrel{1}{1} \\
\stackrel{7}{7} \\
0\end{array}$ & $\begin{array}{l}n \\
a \\
0 \\
0 \\
0\end{array}$ \\
\hline & $\begin{array}{l} \\
\pi \\
0 \\
0 \\
0 \\
0 \\
0 \\
0 \\
0 \\
0\end{array}$ & $\begin{array}{l}0 \\
\frac{\pi}{0} \\
0 \\
0 \\
0 \\
0 \\
0 \\
0 \\
0 \\
0 \\
0\end{array}$ & 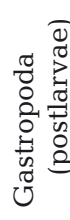 & $\sum_{\infty}^{0}$ & 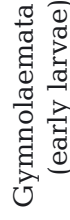 & 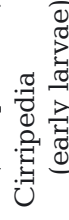 & : & 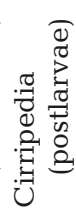 & 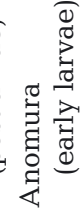 & 离 & 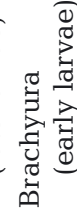 & 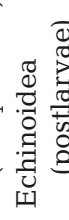 & $\begin{array}{l}0 \\
0 \\
0 \\
0 \\
0 \\
0 \\
0 \\
0 \\
0 \\
0 \\
0 \\
0 \\
0\end{array}$ & 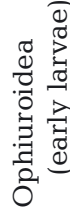 & 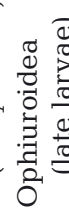 & 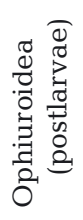 \\
\hline
\end{tabular}




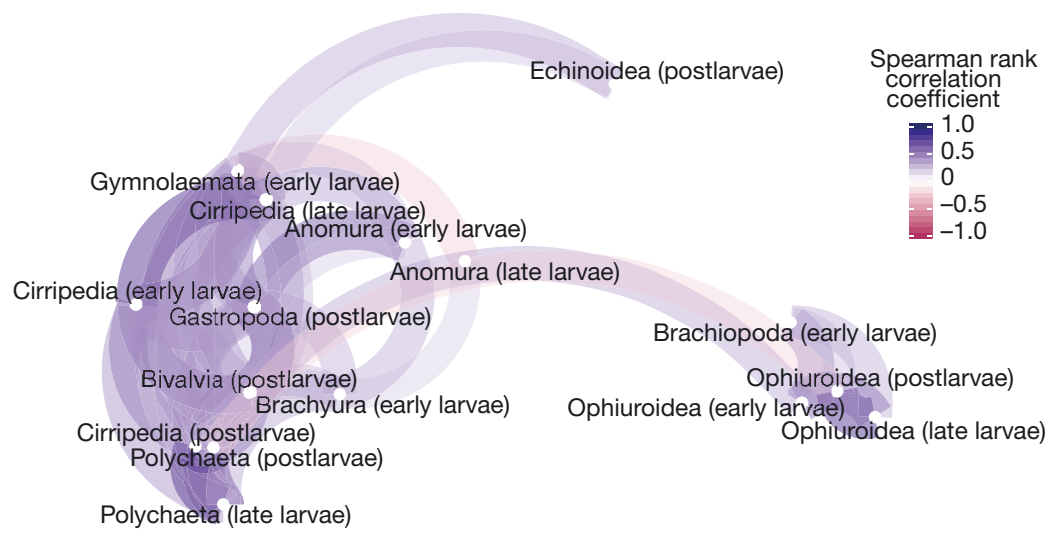

Fig. 5. Network of developmental stages for 10 larval taxa collected from northern Monterey Bay in 2013. Nodes represent larval taxa and stage and edges represent significant Spearman rank correlation coefficients between total abundances (dark purple indicates significant positive correlations and red indicates significant negative correlations). Variables that are more highly correlated appear closer together. Spearman rank correlation coefficients and associated significance values are reported in Table 3. Taxa that were absent or rare across both sampling periods ( 3 or fewer samples with non-0 abundances within a sampling period) are not displayed

types in August (Table 2, Fig. S2b) and fresher offshore water in October (Table 2, Fig. S3b). Although larvae of a few nearshore taxa were associated with relatively warm water in August and relatively saline water in October, the pattern was not widespread because nearshore species may be retained in water types that become increasingly mixed over time, thereby obscuring their water type history.

Most taxa with similar adult habitat (nearshore versus offshore) co-occurred in larval samples (Table 3 , Fig. 5). Therefore, larvae that are released from similar habitats and have similar depth preferences may end up in water types with similar water type histories, as characterized by cross-shore distance, temperature, and salinity. For example, most nearshore taxa were correlated with one another. The nearshore taxa that were the most highly correlated were Polychaeta and Cirripedia, both of which were significantly associated with depth and occurred in significantly higher abundances inshore during both months. All offshore taxa were correlated with each other, found in higher abundances offshore, and significantly associated with depth. All larval stages (early larvae, late larvae, and postlarvae) of Cirripedia, Polychaeta, and Ophiuroidea were highly correlated with each other, suggesting that the various larval stages within a given taxon remained in similar water types throughout larval development. Anomura early and late stages did not co-occur, which suggests that they may have undertaken ontogenetic vertical migrations between surface and bottom waters, although it is still unknown whether they undergo ontogenetic vertical migration (Morgan \& Fisher 2010).

\subsection{Conclusions}

The distribution of benthic invertebrate larvae within northern Monterey Bay appears to be strongly influenced by adult habitat distribution (nearshore versus offshore), vertical positioning of larvae in the water column (depth regulation and foraging), and changing oceanographic conditions (persistence of the upwelling shadow and the intrusion of offshore water). All of these factors interact to create associations between the composition of larval assemblages and water type characteristics, such that larvae of all stages from similar adult habitats cooccur in similar plankton samples. These results are consistent with other studies demonstrating that oceanographic processes coupled with larval behavior are important in explaining patterns of cross-shelf distributions and larval supply in upwelling regions (Poulin et al. 2002a,b, Shanks \& Brink 2005, dos Santos et al. 2007, Morgan et al. 2009a,b, 2018, Shanks \& Shearman 2009, Morgan \& Fisher 2010, Nickols et al. 2013).

Overall, larvae of nearshore taxa tended to be concentrated in the inner bay and near the bottom, throughout development. By remaining near the bottom, shoreward-flowing bottom currents may have retained most larvae nearshore (Morgan et al. 2009a, 2018, Morgan \& Fisher 2010). Late stage larvae of offshore species, such as Ophiuroidea, were not present during upwelling conditions (August), but were observed in the offshore, less saline, bottom water during weakened upwelling conditions (October). Hence, stronger onshore currents during weakened upwelling may have kept the late stage larvae in the sampling domain (Satterthwaite et al. 2020). Offshore postlarvae occurred near the bottom in both months, suggesting that they descended to deeper, soft sediment habitats prior to settlement.

Most studies in upwelling systems have focused on specific nearshore species of barnacles and crabs. Our study is novel in that we sampled larvae originating from across the continental shelf and identi- 
fied a greater array of taxa than has previously been studied. Larvae from adults living in similar habitats exhibited similar spatial distributions, and these patterns persisted among different ocean conditions. Therefore, it is important to consider not only physical oceanographic factors coupled with larval behavior, but also habitat characteristics of the benthic adults, such as the depth and geographic range, when defining factors that govern larval distributions in upwelling regions. These aspects of invertebrate life histories must be integrated when attempting to elucidate drivers of larval transport, supply, and population dynamics of benthic marine organisms.

Acknowledgements. We thank R. Vrijenhoek for encouraging this collaborative project, obtaining the requisite ship time, and for helpful discussion. We also thank the crew of the RV 'Rachel Carson,' the AUV 'Dorado' team, and M. Salisbury for logistical support. We are grateful to J. Largier for his valuable insight and feedback on the manuscript and B. Gaylord for his helpful comments. We also thank S. Bashevkin, C. Dibble, H. Killeen, E. Kiskaddon, A. Shain, and M. Minton for laboratory assistance. This research was supported by a National Science Foundation Graduate Research Fellowship (1650042) and the David and Lucille Packard Foundation (MBARI project 901026).

\section{LITERATURE CITED}

Bartilotti C, dos Santos A, Castro M, Peliz Á, Santos AMP (2014) Decapod larval retention within distributional bands in a coastal upwelling ecosystem. Mar Ecol Prog Ser 507:233-247

Bonicelli J, Tyburczy J, Tapia FJ, Finke GR and others (2016) Diel vertical migration and cross-shore distribution of barnacle and bivalve larvae in the central Chile inner-shelf. J Exp Mar Biol Ecol 485:35-46

Carleton JT (ed) (2007) Light and Smith manual: intertidal invertebrates from central California to Oregon, $4^{\text {th }}$ edn, completely revised and expanded. University of California Press, Berkeley, CA

Chavez FP, Messié M (2009) A comparison of eastern boundary upwelling ecosystems. Prog Oceanogr 83: 80-96

Clarke KR, Warwick RM (2001) Change in marine communities: an approach to statistical analysis and interpretation, $2^{\text {nd }}$ edn. PRIMER-E, Plymouth

DiBacco C, Fuchs HL, Pineda J, Helfrich K (2011) Swimming behavior and velocities of barnacle cyprids in a downwelling flume. Mar Ecol Prog Ser 433:131-148

dos Santos A, Santos AMP, Conway DVP (2007) Horizontal and vertical distribution of cirripede cyprid larvae in an upwelling system off the Portuguese coast. Mar Ecol Prog Ser 329:145-155

Eckman JE (1996) Closing the larval loop: linking larval ecology to the population dynamics of marine benthic invertebrates. J Exp Mar Biol Ecol 200:207-237

Epifanio, CE, Cohen JH (2016) Behavioral adaptations in larvae of brachyuran crabs: a review. J Exp Mar Biol Ecol 482:85-105
Fauchald K, Jumars PA (1979) The diet of worms: a study of polychaete feeding guilds. Oceanogr Mar Biol Annu Rev 17:193-284

Fisher JL, Peterson WT, Morgan SG (2014) Does larval advection explain latitudinal differences in recruitment across upwelling regimes? Mar Ecol Prog Ser 503: 123-137

Gaines SD, Roughgarden J (1987) Fish in offshore kelp forests affect recruitment to intertidal barnacle population. Science 235:479-481

Graham WM, Largier JL (1997) Upwelling shadows as nearshore retention sites: the example of northern Monterey Bay. Cont Shelf Res 17:509-532

Graham WM, Field JG, Potts DC (1992) Persistent 'upwelling shadows' and their influence on zooplankton distributions. Mar Biol 114:561-570

* Hameed SO, Elliott ML, Morgan SG, Jahncke J (2018) Interannual variation and spatial distribution of decapod larvae in a region of persistent coastal upwelling. Mar Ecol Prog Ser 587:55-71

*Harvey JBJ, Fisher JL, Ryan JP, Johnson SB, Peterson WT, Vrijenhoek RC (2018) Changes in zooplankton assemblages in northern Monterey Bay, California, during a fall transition. Mar Ecol Prog Ser 604:99-120

* Hothorn T, Bretz F, Westfall P (2008) Simultaneous inference in general parametric models. Biom J 50:346-363

Jackman S (2020). pscl: classes and methods for R developed in the Political Science Computational Laboratory. United States Studies Centre, Sydney. R package version 1.5.5, https://github.com/atahk/pscl/

Lasker R (1975) Field criteria for survival of anchovy larvae: the relation between inshore chlorophyll maximum layers and successful first feeding. Fish Bull 73:453-462

* Levin LA (2006) Recent progress in understanding larval dispersal: new directions and digressions. Integr Comp Biol 46: 282-97

Mace AJ, Morgan SG (2006) Biological and physical coupling in the lee of a small headland: contrasting transport mechanisms for crab larvae in an upwelling region. Mar Ecol Prog Ser 324:185-196

McManus MA, Kudela RM, Silver MW, Steward GF, Donaghay PL, Sullivan JM (2008) Cryptic blooms: Are thin layers the missing connection? Estuar Coast 31:396-401

*Miller SH, Morgan SG (2013) Interspecific differences in depth preference: regulation of larval transport in an upwelling system. Mar Ecol Prog Ser 476:301-306

Morgan SG (2014) Behaviorally mediated larval transport in upwelling systems. Adv Oceanogr 2014:364214

Morgan SG (2020) Dispersal. In: Anger K, Harzsch S, Thiel M (eds) The natural history of the Crustacea, Vol VII. Developmental biology and larval ecology. Academic Press, New York, NY, p 383-407

* Morgan SG, Fisher JL (2010) Larval behavior regulates nearshore retention and offshore migration in an upwelling shadow and along the open coast. Mar Ecol Prog Ser 404:109-126

Morgan SG, Fisher JL, Miller SH, McAfee ST, Largier JL (2009a) Nearshore larval retention in a region of strong upwelling and recruitment limitation. Ecology 90: 3489-3502

Morgan SG, Fisher JL, Mace AJ (2009b) Larval recruitment in a region of strong, persistent upwelling and recruitment limitation. Mar Ecol Prog Ser 394:79-99

Morgan SG, Fisher JL, Mace AJ, Akins L, Slaughter AM, Bollens SM (2009c) Cross-shelf distributions and recruit- 
ment of crab postlarvae in a region of strong upwelling. Mar Ecol Prog Ser 380:173-185

Morgan SG, White JW, McAfee ST, Gaines SD, Schmitt RJ (2011a) Weak synchrony in the timing of larval release in upwelling regimes. Mar Ecol Prog Ser 425:103-112

Morgan SG, Fisher JL, Largier JL (2011b) Larval retention, entrainment, and accumulation in the lee of a small headland: recruitment hotspots along windy coasts. Limnol Oceanogr 56:161-178

* Morgan SG, Miller SH, Robart MJ, Largier JL (2018) Nearshore larval retention and cross-shelf migration of benthic crustaceans at an upwelling center. Front Mar Sci 5:161

Nickols KJ, Miller SH, Gaylord B, Morgan SG, Largier JL (2013) Spatial differences in larval abundance within the coastal boundary layer impact supply to shoreline habitats. Mar Ecol Prog Ser 494:191-203

Oksanen J, Blanchet GF, Friendly M, Kindt R and others (2018) vegan: Community ecology package. R package version 2.5-7. https://CRAN.R-project.org/package=vegan

Pauly D, Christensen V (1995) Primary production required to sustain global fisheries. Nature 374:255-257

* Pennington JT, Chavez FP (2000) Seasonal fluctuations of temperature, salinity, nitrate, chlorophyll and primary production at Station H3/M1 over 1989-1996 in Monterey Bay, California. Deep Sea Res II 47:947-973

* Phelan PJ, Steinbeck J, Walter RK (2018) Influence of internal bores on larval fish abundance and community composition. Reg Stud Mar Sci 20:1-12

*Pineda J (1991) Predictable upwelling and the shoreward transport of planktonic larvae by internal tidal bores. Science 253:548-549

* Pineda J, Hare J, Sponaugle S (2007) Larval transport and dispersal in the coastal ocean and consequences for population connectivity. Oceanography 20:22-39

* Poulin E, Palma AT, Leiva G, Hernández E, Martinez P, Navarrete SA, Castilla JC (2002a) Temporal and spatial variation in the distribution of epineustonic competent larvae of Concholepas concholepas along the central coast of Chile. Mar Ecol Prog Ser 229:95-104

* Poulin E, Palma AT, Leiva G, Narvaez D, Pacheco R, Navarrete SA, Castilla JC (2002b) Avoiding offshore transport of competent larvae during upwelling events: the case of the gastropod Concholepas concholepas in central Chile. Limnol Oceanogr 47:1248-1255

Queiroga H, Blanton J (2004) Interactions between behaviour and physical forcing in the control of horizontal transport of decapod crustacean larvae. Adv Mar Biol 47: 107-214

Roughan M, Mace AJ, Largier JL, Morgan SG, Fisher JL, Carter ML (2005) Subsurface recirculation and larval retention in the lee of a small headland: a variation on the upwelling shadow theme. J Geophys Res 110:C10027

Roughgarden J, Gaines S, Possingham H (1988) Recruitment dynamics in complex life cycles. Science 241: 1460-1466

Ryan JP, Fischer AM, Kudela RM, McManus MA and others (2010a) Recurrent frontal slicks of a coastal ocean upwelling shadow. J Geophys Res 115:C12070

Ryan JP, McManus MA, Sullivan JM (2010b) Interacting physical, chemical and biological forcing of phytoplankton thin-layer variability in Monterey Bay, California. Cont Shelf Res 30:7-16

Ryan JP, McManus MA, Kudela RM, Lara Artigas M and others (2014a) Boundary influences on HAB phyto-

Editorial responsibility: Stephen Wing,

Dunedin, New Zealand

Reviewed by: J. Jarrett, H. Queiroga and 1 anonymous referee plankton ecology in a stratification-enhanced upwelling shadow. Deep Sea Res II 101:63-79

* Ryan JP, Harvey JBJ, Zhang Y, Woodson CB (2014b) Distributions of invertebrate larvae and phytoplankton in a coastal upwelling system retention zone and peripheral front. J Exp Mar Biol Ecol 459:51-60

Satterthwaite EV, Morgan SG, Ryan JP, Harvey JBJ, Vrijenhoek RC (2020) Seasonal and synoptic oceanographic changes influence the larval biodiversity of a retentive upwelling shadow. Prog Oceanogr 182:102261

Shanks AL, Brink L (2005) Upwelling, downwelling, and cross-shelf transport of bivalve larvae: test of a hypothesis. Mar Ecol Prog Ser 302:1-12

Shanks AL, Shearman RK (2009) Paradigm lost? Cross-shelf distributions of intertidal invertebrate larvae are unaffected by upwelling or downwelling. Mar Ecol Prog Ser 385:189-204

Shanks AL, Wright WG (1987) Internal-wave-mediated shoreward transport of cyprids, megalopae, and gammarids and correlated longshore differences in the settling rate of intertidal barnacles. J Exp Mar Biol Ecol 114: $1-13$

Strathmann RR (1985) Feeding and nonfeeding larval development and life-history evolution in marine invertebrates. Annu Rev Ecol Syst 16:339-361

Thorson G (1950) Reproductive and larval ecology of marine bottom invertebrates. Biol Rev Camb Philos Soc 25:1-45

Turner JT, Levinsen H, Nielsen TG, Hansen BW (2001) Zooplankton feeding ecology: grazing on phytoplankton and predation on protozoans by copepod and barnacle nauplii in Disko Bay, West Greenland. Mar Ecol Prog Ser 221:209-219

* Vargas CA, Manriquez PH, Navarrete SA (2006) Feeding by larvae of intertidal invertebrates: assessing their position in pelagic food webs. Ecology 87:444-457

Venables WN, Ripley BD (2002) Modern applied statistics with S, $4^{\text {th }}$ edn. Springer, New York, NY

* Vuong QH (1989) Likelihood ratio tests for model selection and non-nested hypotheses. Econometrica 57:307-333

W Walter RK, Woodson CB, Arthur RS, Fringer OB, Monismith SG (2012) Nearshore internal bores and turbulent mixing in southern Monterey Bay. J Geophys Res 117:C07017

Wing SR, Botsford LW, Largier JL, Morgan LE (1995) Spatial structure of relaxation events and crab settlement in the northern California upwelling system. Mar Ecol Prog Ser 128:199-211

*Wing SR, Botsford LW, Ralston SV, Largier JL (1998) Meroplanktonic distribution and circulation in a coastal retention zone of the northern California upwelling system. Limnol Oceanogr 43:1710-1721

WWoodson CB, McManus MA (2007) Foraging behavior can influence dispersal of marine organisms. Limnol Oceanogr 52:2701-2709

*Woodson CB, McManus MA, Tyburczy JA, Barth JA and others (2012) Coastal fronts set recruitment and connectivity patterns across multiple taxa. Limnol Oceanogr 57 : 582-596

Yoshioka PM (1982) Role of planktonic and benthic factors in the population dynamics of the bryozoan Membranipora membranacea. Ecology 63:457-468

Young CM (1995) Behavior and locomotion during the dispersal phase of larval life. In: McEdward L (ed) Ecology of marine invertebrate larvae. CRC Press, Boca Raton, FL, p 249-277

Submitted: May 22, 2020;

Accepted: November 30, 2020

Proofs received from author(s): March 2, 2021 